\title{
HRAC Classification of Herbicides and Resistance Development
}

\author{
Hubert Menne and Helmut Köcher
}

\section{1 \\ Introduction}

The first cases of herbicide resistance were reported around 1970. Since then resistance of mono- and dicotyledonous weeds to herbicides has become an increasing problem world-wide.

In March 2006 the International Survey of Herbicide-Resistant Weeds recorded 305 herbicide-resistant biotypes with 182 weed species - 109 dicotyledonous and 73 monocotyledonous weeds [1]. The relatively steady increase in the number of new cases of resistance since 1980 accounts for the increasing importance of herbicide resistance in weeds in the major agricultural regions (Fig. 1.1).

In the period 1970-1990 most documented cases were concerning triazine resistance. The introduction of new herbicides with different modes of action (MoA) resulted in a shift, so that more recently ALS- and ACCase resistant weeds have been reported (Fig. 1.2).

The rapid adoption of glyphosate resistant crops in North and South America and the use of glyphosate as a pre-sowing treatment in different cropping systems has resulted in increasing cases of glyphosate resistance [1]. The probability of resistance development to glyphosate had been expressed as being likely, though less frequently in comparison with most mode of action classes [2].

\section{2}

\section{HRAC Classification System of Herbicides}

The global HRAC group proposed a classification system for herbicides according to their target sites, modes of action, similarity of induced symptoms or chemical classes (Table 1.1).

It is the most comprehensive existing classification system of herbicides globally. With the WSSA Code System and Australian Code System two similar classification systems were developed earlier for regional needs. The usage of differ- 


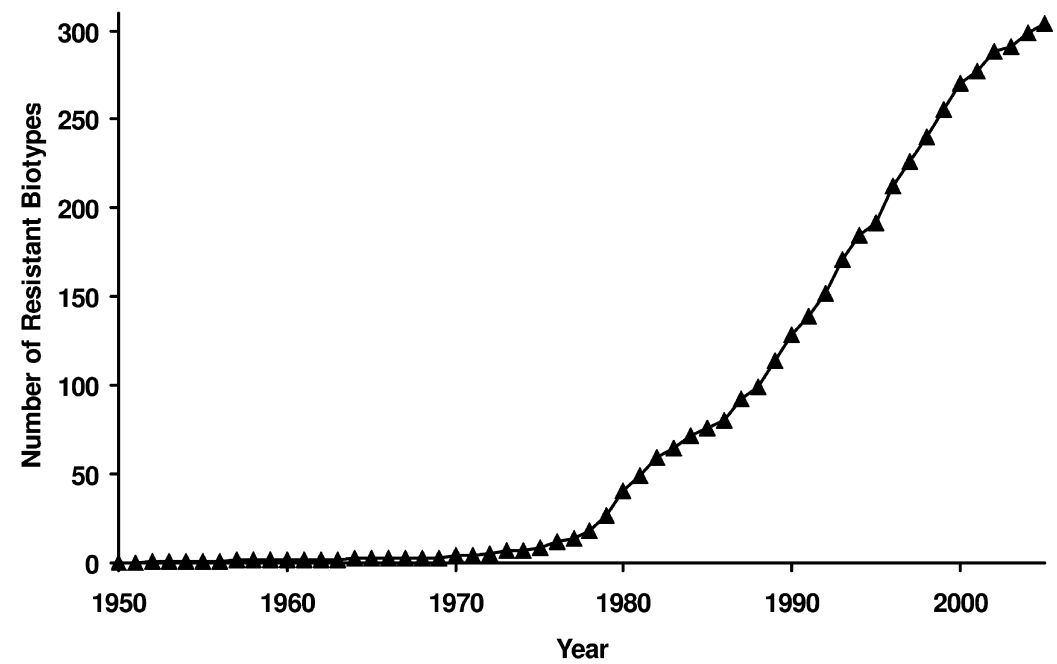

Fig. 1.1. Chronological increase in the number of herbicide-resistant weeds worldwide [3].

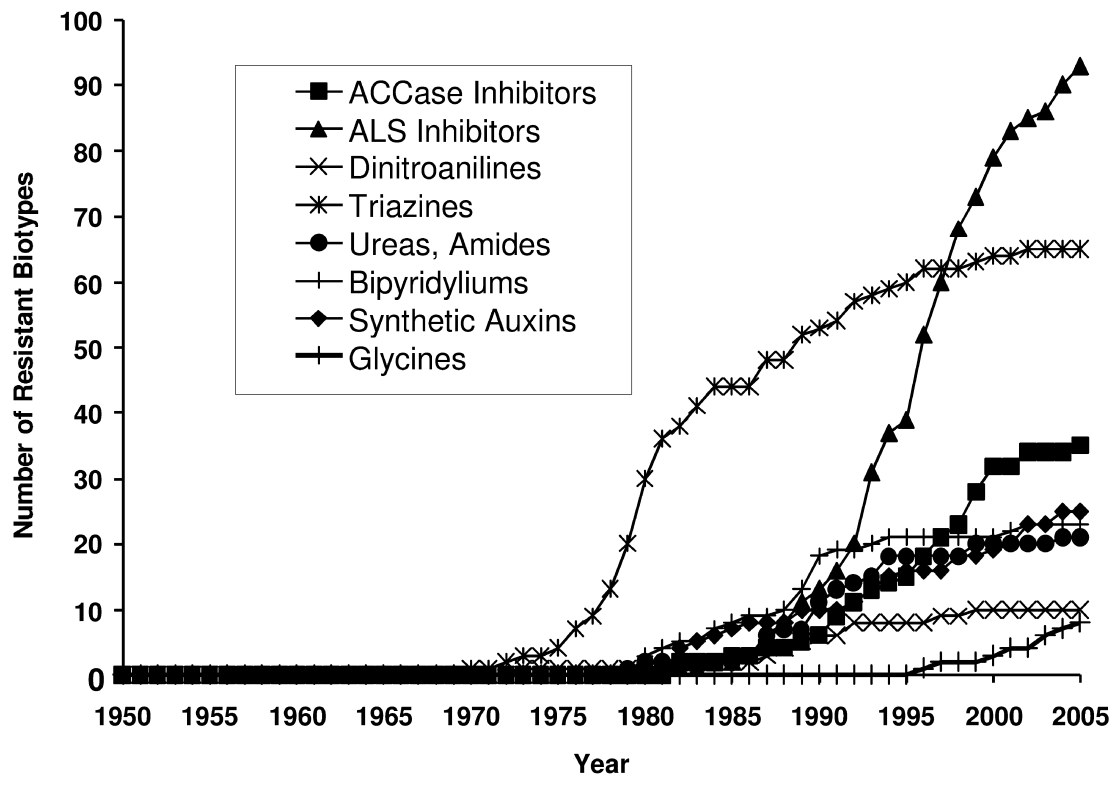

Fig. 1.2. Chronological increase in the number of herbicide-resistant weeds for the different herbicide classes [3]. 
Table 1.1 HRAC classification system in comparison to WSSA and Australian code system. (Adapted from Refs. [3-5].)

\begin{tabular}{|c|c|c|c|c|}
\hline Mode of action & Chemical family & $\begin{array}{l}\text { HRAC } \\
\text { group }\end{array}$ & $\begin{array}{l}\text { WSSA } \\
\text { group }^{[a]}\end{array}$ & $\begin{array}{l}\text { Australian } \\
\text { group }^{[a]}\end{array}$ \\
\hline $\begin{array}{l}\text { Inhibition of acetyl CoA } \\
\text { carboxylase (ACCase) }\end{array}$ & $\begin{array}{l}\text { Aryloxyphenoxy-propionate, } \\
\text { cyclohexanedione, } \\
\text { phenylpyrazoline }\end{array}$ & A & 1 & A \\
\hline $\begin{array}{l}\text { Inhibition of acetolactate } \\
\text { synthase ALS } \\
\text { (acetohydroxyacid synthase } \\
\text { AHAS) }\end{array}$ & $\begin{array}{l}\text { Sulfonylurea, } \\
\text { imidazolinone, } \\
\text { triazolopyrimidine, } \\
\text { pyrimidinyl(thio)benzoate, } \\
\text { sulfonylaminocarbonyl- } \\
\text { triazolinone }\end{array}$ & $\mathrm{B}$ & 2 & $\mathrm{~B}$ \\
\hline \multirow[t]{3}{*}{$\begin{array}{l}\text { Inhibition of photosynthesis } \\
\text { at photosystem II }\end{array}$} & $\begin{array}{l}\text { Triazine, triazinone, } \\
\text { triazolinone, uracil, } \\
\text { pyridazinone, phenyl- } \\
\text { carbamate }\end{array}$ & $\mathrm{C} 1$ & 5 & $\mathrm{C} / \mathrm{K}$ \\
\hline & Urea, amide & $\mathrm{C} 2$ & 7 & $\mathrm{C}$ \\
\hline & $\begin{array}{l}\text { Nitrile, benzothiadiazinone, } \\
\text { phenyl-pyridazine }\end{array}$ & $\mathrm{C} 3$ & 6 & $\mathrm{C}$ \\
\hline $\begin{array}{l}\text { Photosystem-I-electron } \\
\text { diversion }\end{array}$ & Bipyridylium & $\mathrm{D}$ & 22 & $\mathrm{~L}$ \\
\hline $\begin{array}{l}\text { Inhibition of protopor- } \\
\text { phyrinogen oxidase (PPO) }\end{array}$ & $\begin{array}{l}\text { Diphenyl ether, } \\
\text { phenylpyrazole, } \\
\text { N-phenylphthalimide, } \\
\text { thiadiazole, oxadiazole, } \\
\text { triazolinone, } \\
\text { oxazolidinedione, } \\
\text { pyrimidindione, other }\end{array}$ & $\mathrm{E}$ & 14 & G \\
\hline $\begin{array}{l}\text { Inhibition of the phytoene } \\
\text { desaturase (PDS) }\end{array}$ & $\begin{array}{l}\text { Pyridazinone, } \\
\text { pyridinecarboxamide, other }\end{array}$ & F1 & 12 & $\mathrm{~F}$ \\
\hline $\begin{array}{l}\text { Inhibition of 4- } \\
\text { hydroxyphenyl-pyruvate- } \\
\text { dioxygenase (4-HPPD) }\end{array}$ & $\begin{array}{l}\text { Triketone, isoxazole, } \\
\text { pyrazole, other }\end{array}$ & F2 & 27 & $\mathrm{~F}$ \\
\hline $\begin{array}{l}\text { Inhibition of carotenoid } \\
\text { biosynthesis (unknown } \\
\text { target) }\end{array}$ & $\begin{array}{l}\text { Triazole, diphenylether, } \\
\text { urea (also C2) }\end{array}$ & F3 & 11 & $\mathrm{~F}$ \\
\hline $\begin{array}{l}\text { Inhibition of 1-deoxy-D- } \\
\text { xylulose } 5 \text {-phosphate } \\
\text { synthase (DOXP synthase) }\end{array}$ & Isoxazolidinone & F4 & 13 & $\mathrm{~F}$ \\
\hline Inhibition of EPSP synthase & Glycine & G & 9 & M \\
\hline
\end{tabular}


Table 1.1 (continued)

\begin{tabular}{|c|c|c|c|c|}
\hline Mode of action & Chemical family & $\begin{array}{l}\text { HRAC } \\
\text { group }\end{array}$ & $\begin{array}{l}\text { WSSA } \\
\text { group }^{[a]}\end{array}$ & $\begin{array}{l}\text { Australian } \\
\text { group }^{[a]}\end{array}$ \\
\hline $\begin{array}{l}\text { Inhibition of glutamine } \\
\text { synthetase }\end{array}$ & Phosphinic acid & $\mathrm{H}$ & 10 & $\mathrm{~N}$ \\
\hline $\begin{array}{l}\text { Inhibition of DHP } \\
\text { (dihydropteroate) synthase }\end{array}$ & Carbamate & I & 18 & $\mathrm{~K}$ \\
\hline $\begin{array}{l}\text { Inhibition of microtubule } \\
\text { assembly }\end{array}$ & $\begin{array}{l}\text { Dinitroaniline, } \\
\text { phosphoroamidate, } \\
\text { pyridine, benzamide, } \\
\text { benzoic acid }\end{array}$ & K1 & 3 & $\mathrm{D} / \mathrm{K}$ \\
\hline $\begin{array}{l}\text { Inhibition of mitosis/ } \\
\text { microtubule organisation }\end{array}$ & Carbamate & $\mathrm{K} 2$ & 23 & $\mathrm{E}$ \\
\hline $\begin{array}{l}\text { Inhibition of VLCFAs } \\
\text { (inhibition of cell division) }\end{array}$ & $\begin{array}{l}\text { Chloroacetamide, } \\
\text { acetamide, oxyacetamide, } \\
\text { tetrazolinone, other }\end{array}$ & K3 & 15 & $\mathrm{~K}$ \\
\hline \multirow{4}{*}{$\begin{array}{l}\text { Inhibition of cell wall } \\
\text { (cellulose) synthesis }\end{array}$} & Nitrile & $\mathrm{L}$ & 20 & $\mathrm{~K}$ \\
\hline & Benzamide & $\mathrm{L}$ & 21 & \\
\hline & Triazolocarboxamide & $\mathrm{L}$ & & \\
\hline & Quinoline carboxylic acid & $\mathrm{L}$ & 26 & \\
\hline $\begin{array}{l}\text { Uncoupling (membrane } \\
\text { disruption) }\end{array}$ & Dinitrophenol & M & 24 & \\
\hline \multirow[t]{3}{*}{$\begin{array}{l}\text { Inhibition of lipid synthesis } \\
\text { - not ACCase inhibition }\end{array}$} & $\begin{array}{l}\text { Thiocarbamate, } \\
\text { phosphorodithioate }\end{array}$ & $\mathrm{N}$ & 8 & $\mathrm{E}$ \\
\hline & Benzofuran & $\mathrm{N}$ & 16 & $\mathrm{~K}$ \\
\hline & Chloro-carbonic-acid & $\mathrm{N}$ & 26 & $\mathrm{~J}$ \\
\hline $\begin{array}{l}\text { Action like indole acetic } \\
\text { acid (synthetic auxins) }\end{array}$ & $\begin{array}{l}\text { Phenoxy-carboxylic-acid, } \\
\text { benzoic acid, pyridine } \\
\text { carboxylic acid, quinoline } \\
\text { carboxylic acid, other }\end{array}$ & $\mathrm{O}$ & 4 & I \\
\hline $\begin{array}{l}\text { Inhibition of auxin } \\
\text { transport }\end{array}$ & $\begin{array}{l}\text { Phthalamate, } \\
\text { semicarbazone }\end{array}$ & $\mathrm{P}$ & 19 & \\
\hline Unknown & Arylaminopropionic acid & $\mathrm{Z}$ & 25 & $\mathrm{~K}$ \\
\hline Note: While the mode of & Pyrazolium & $\mathrm{Z}$ & 26 & \\
\hline action of herbicides in & Organoarsenical & $\mathrm{Z}$ & 17 & \\
\hline $\begin{array}{l}\text { Group } \mathrm{Z} \text { is unknown it is } \\
\text { likely that they differ in } \\
\text { mode of action between } \\
\text { themselves and from other } \\
\text { groups }\end{array}$ & Other & $\mathrm{Z}$ & 27 & \\
\hline
\end{tabular}

a Not all chemical classes are classified. 
ent numbers and letters in the different classification systems lead very often to confusion and misunderstanding on the global level. One common global system would be highly desirable for all users and for better understanding of differences between molecular classes. All single systems should give support and advice to all users of herbicides. This advice should state how to apply the individual active compounds to achieve the best results in terms of weed control and resistance management.

The classification system is describing not only the chemical family belonging to a specific mode of action but all compounds via their common names counted to each family, as shown in Table 1.2 for the modes of action such as "Inhibition of DHP (dihydropteroate) synthase", "Microtubule assembly inhibition”, "Inhibition of mitosis/microtubule organization", "Inhibition of VLCFAs (Inhibition of cell division)" and "Inhibition of cell wall (cellulose) synthesis" as examples (not mentioned in other chapters of this book) (for a detailed table see www .plantprotection.org/HRAC/). The scheme "The World of Herbicides" available under this internet address also shows all chemical structures of the different herbicides belonging to the different chemical families.

\section{3}

\section{Herbicide Resistance}

In the weed population, herbicide resistance in weeds is a natural phenomenon that occurs at a low frequency and which has evolved over millions of years. Herbicide applications only select for these weeds in a population but they do not cause resistance. Increasing problems with herbicide resistant weed populations have predominantly occurred in countries with intensive agriculture cropping systems. The reliance on few of the available weed management tools with disregard of the principles of Integrated Weed Management (IWM) are closely related to changes in the weed population community. Changes in the farming environment and specifically the economic pressure on farmers are key factors that force farmers to change their practices to those that encourage resistance development.

The limitation in cropping systems, lack of rotation of herbicide chemistry or mode of action, limitation in weed control techniques, reduction of dose rates, etc. are major drivers for the selection of herbicide resistances. Regular country based surveys often make clear that farmers are aware of the problems and their causes. A survey in Germany in 2004 showed that $94 \%$ of the farmers are aware that the repeated use of the same herbicide, and $89 \%$ that the reduction of dose rates, causes the development of herbicide resistance. However, $86 \%$ of the farmers are forced to reduce their costs and they do not have a lot of scope with their weed management techniques [6].

As mentioned previously, the planting of herbicide resistant crops worldwide, which increased from $1.7 \mathrm{mio} \mathrm{ha}^{-1}$ in 1996 to around $90 \mathrm{mio} \mathrm{ha}^{-1}$ in 2005, has changed the farmers weed control tactic completely [7]. These systems have provided the farmers favorable economic advantages as well as more cropping flexi- 
Table 1.2 Selected groups of the HRAC classification system with examples of the active ingredients, which are not mentioned in following chapters. (Adapted from Refs. [3-5].)

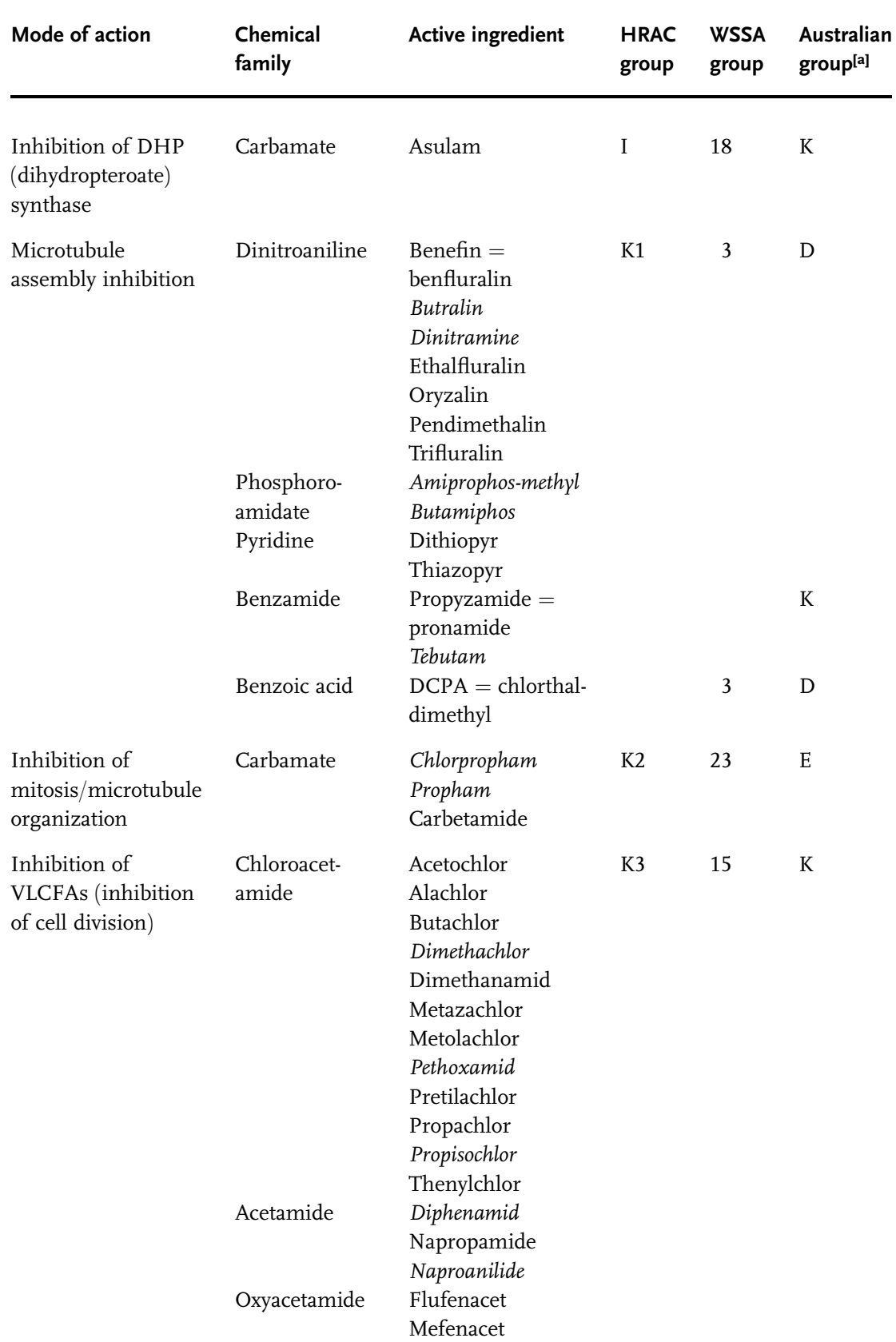


Table 1.2 (continued)

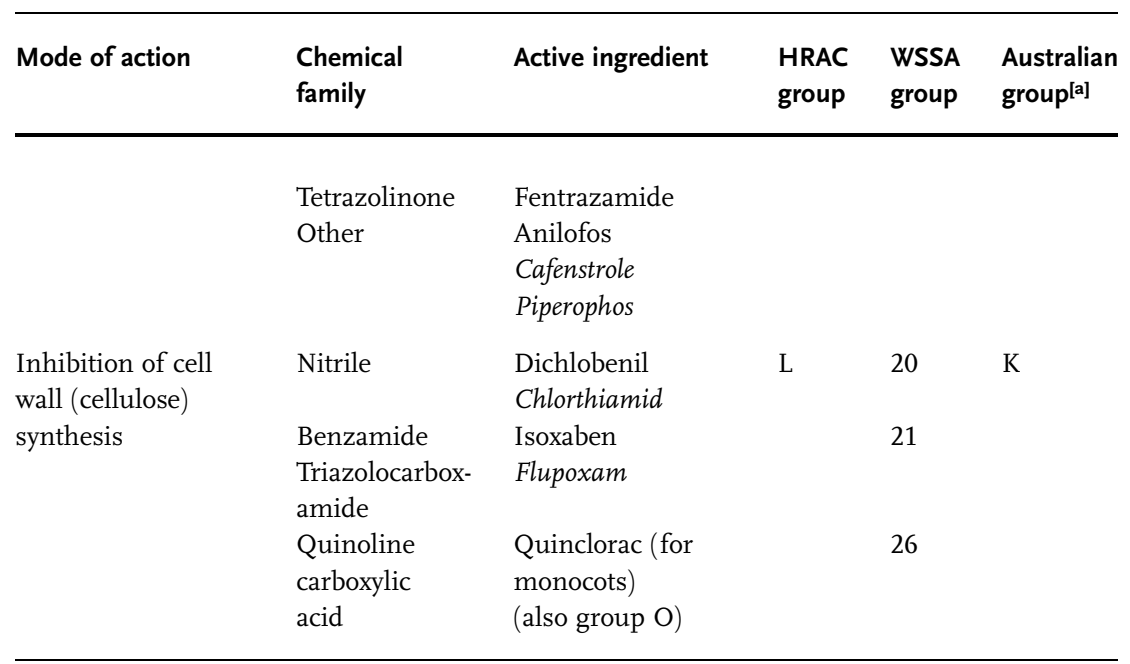

a Not all chemical classes are classified.

bility. In Canada the adoption of herbicide resistant cropping systems has already reached 5.2 million ha (95\%) out of 5.5 million ha for canola production [8].

The reliance on one herbicide has reduced the number of applications and the number of MoA used. In 2004, glyphosate was applied on $87 \%$ (62\% in 2000, $25 \%$ in 1996) of the whole acreage of soybeans in the US [9]. No other herbicide was applied on more than $7 \%$ of the acreage (four herbicides with more than $10 \%$ in 2000) [9].

The continued use of herbicide resistant cropping systems with over-reliance on single weed management techniques selects for weeds that have already evolved resistance to the herbicide. Additionally, in the population, specific weed species can become dominant that were less frequent before but naturally resistant and, therefore, more difficult to control. It was suspected that a weed population shift will have a bigger impact on the cropping system than the selection of resistant weeds $[10,11]$. Recent research studies and findings suggest that resistance in weeds and weed populations shifts are occurring more quickly than expected [12]. Statistical observations have shown that the use, dose rates and application frequency have already changed. In the US in 1996 glyphosate was applied in soybeans 1.1 times with $773 \mathrm{~g}$-a.i. $\mathrm{ha}^{-1}$. The usage increased to 1.3 applications and 1065 g-a.i. ha ${ }^{-1}$ in 2000, to 1.5 applications and 1211 g-a.i. ha ${ }^{-1}$ in 2004 [9]. Similar trends can be observed for corn and cotton and also for soybeans in other countries like Argentina and Brazil.

Intensive soil cultivation techniques and stubble burning were always common weed control techniques in agricultural areas in the past. The increasing limitation or ban of stubble burning caused increasing weed coverage, an increasing 
soil seed bank and the development of herbicide resistance in many agricultural regions. Different investigations have shown that the burning of straw drastically decreased weed densities, e.g., the number of waterplants (Echinochloa spp.) in comparison to the incorporation of rice straw into the soil [13]. Australian farmers in particular look for alternative weed control techniques during the harvest operation because of the limited choice of chemical solutions during the growing season. Balling of straw methods, such as trailing baler attached to the harvester or destroying of weed seeds physically during the harvesting operation ("Rotomill"), gives additional possibilities [14].

The economic pressure to farmers to produce at lowest costs and the changing environmental influences, like soil erosion or water availability, have led to the adoption of no-till practices in recent years. The use of no-till is expected to further increase globally. In most cases the shift to no-till systems causes an over reliance on herbicides. The price erosion of herbicides during the last years played a significant role in adoption of no-till practices. Survey studies showed that farmers are aware that no-till practices increase herbicides costs, herbicide resistance and in particular glyphosate resistance. Nevertheless, the acreage for no-till is expected to increase, especially in areas where no-till is still of low proportion [15]. However, growers with increasing herbicide resistance problems were planning to reduce the use of no-till.

Simulation studies showed that the risk of adopting no-till and the development of herbicide resistances can be reduced by alternating between minimum and no-tillage systems or by alternating between non-selective herbicides for presowing weed control [16]. The most efficient weed control strategy for conserving susceptibility in no-tillage systems was the "double knockdown" pre-sowing application scheme of glyphosate and paraquat in sequence.

One of the most effective tools in the management of herbicide resistance and weed density is a diverse crop rotation practice. Weed species are typically associated with crops, and crop rotations compose their specific weed populations over time [17]. A high diversity provides the farmer more opportunities with more flexibility with respect to growing conditions, tillage practices and planting time, selecting of crop cultivars, rotating herbicides with different modes of action, varying the application timings of herbicides across years to a specific weed emergence period and/or including nonchemical management techniques etc. [18]. These practices give farmers opportunities to prevent or to slow down the selection and development of herbicide resistance. Selected resistance can remain in field populations for many years. They are stable until resistant weed seeds disappear from soil seed banks, which is very seldom. Investigations with triazine resistant weed strains showed that resistant weed seeds remained in soil despite changes in crop rotation and absence of triazine herbicides [19]. Similar results were obtained in studies that evaluated the effect of management practices on ACCase resistant Alopecurus myosuroides in the field [20]. The percentage of resistant plants did not change during a three-year period even without herbicide applications of ACCase inhibitors. The density of blackgrass plants was decreased, however, especially when spring crops were part of the crop rotation. 
Neither cropping systems nor single weed management tactic can solve specific weed problems on a long-term basis. The use of all possible practices to prevent and to manage herbicide resistances in an integrated fashion should be the longterm goal for agricultural production.

As already mentioned, continuous application of a herbicide selects rare genotypes of weeds that are resistant to the herbicide and eventually at the same time already cross-resistant to other herbicides. These genotypes may already exist in a weed population in very low frequency before the introduction of the selecting herbicide.

\subsection{1}

\section{Biochemistry of Herbicide Resistance}

Resistance can be based on one of the following biochemical mechanisms [21]:

Target-site resistance is due to reduced or lost ability of the herbicide to bind to its target protein. This is usually an enzyme with a crucial function in metabolic pathways or the component of an electron transport system. As a further possibility, target-site resistance could also be caused by an overproduction of the herbicide-binding protein.

Nontarget-site resistance is caused by mechanisms that reduce the amount of herbicidally active compound reaching the target site. An important mechanism is enhanced metabolic detoxification of the herbicide in the weed, with the effect that only insufficient amounts of herbicidally active substance will reach the target site. Furthermore, reduced uptake and translocation or sequestration of the herbicide may lead to insufficient herbicide transport to the target site.

Cross-resistance means that a single resistance mechanism causes resistance to several herbicides. The term target-site cross-resistance is used when these herbicides bind to the same target site, whereas nontarget-site cross-resistance is due to a single nontarget-site mechanism (e.g., enhanced metabolic detoxification) that entails resistance across herbicides with different modes of action.

Multiple resistance is a situation where two or more resistance mechanisms are present within individual plants or within a population.

\subsubsection{Target-site Resistance}

Cases analyzed to date show that herbicide resistance is very frequently based on a target-site mutation. Within the past 35 years weed species have developed targetsite resistance to most known herbicide chemistries. Those of major importance are discussed below.

Inhibitors of Photosystem II (PS II) Early reports on resistance of weeds to PSII inhibitors of the triazine group appeared around 1970. Since then triazine resistance was reported for numerous, mainly dicotyledonous, weed species.

Research on the mechanism of resistance to triazines revealed that in most cases it is due to a mutation which results in a modification of the target site which is known to be the $\mathrm{Qb}$ site of the $\mathrm{D} 1$ protein in the PSII reaction center. 
The triazine herbicides bind to this site and thus inhibit the photosynthetic electron flow. In the resistant mutants triazine binding is markedly reduced. As an example, the concentration of atrazine needed to obtain a $50 \%$ inhibition of photosynthetic electron flow in isolated chloroplasts of Chenopodium album was found to be at least $430 \times$ higher for chloroplasts from an atrazine-resistant mutant than for chloroplasts from wild-type plants [22].

In many cases, mutants of weed species with target-site resistance to triazines showed lower growth rate and ecological fitness than the susceptible wild type, when analyzed in absence of a triazine herbicide as selection agent. The quantum yield of $\mathrm{CO}_{2}$ reduction in resistant biotypes was decreased. Furthermore, the electron transfer between the primary and secondary quinones in the PS II reaction center was slowed, which may have been the cause of increased susceptibility to photoinhibition in the resistant biotypes [23, 24].

The D1 protein is encoded by the chloroplast $p s b \mathrm{~A}$ gene, which is a highly conserved gene in higher plants, algae and cyanobacteria [25]. In almost all cases of investigated resistance of weed species in the field to triazines, resistance was attributed to a mutation in the psbA gene with a resultant serine 264 to glycine change in the herbicide binding niche of the D1 protein. Hence this resistance is usually maternally inherited. Though herbicides of the phenylurea group are also inhibitors of the PS II system, cross-resistance of atrazine-resistant mutants with a serine 264 to glycine change has not been observed to phenylureas. It was proposed that the binding sites of triazines and phenylureas are not identical but overlapping [26, 27]. Serine 264 provides a hydrogen bond to atrazine or other herbicides of the triazine group. Substitution of serine 264 by glycine removes this bond, which is important for binding the triazines. According to the concept of overlapping binding sites, hydrogen bonding to serine 264 is not important for phenylureas, due to a different binding geometry, hence phenylurea binding will not be affected by the serine 264 to glycine mutation.

In 1999 Masabni and Zandstra reported on a mutant of Portulaca oleracea with a resistance pattern to PS II inhibitors that was different to most triazine resistant weeds [28]. This mutant was resistant to the phenylureas linuron and diuron, but also cross-resistant to atrazine and other triazines. Sequencing of the D1 protein revealed that in the resistant biotype the serine 264 was replaced by threonine and not by glycine. This was the first report on a serine 264 to threonine mutation on a whole plant level. It was proposed that the serine-to-threonine mutation modified the conformation of the herbicide binding niche at the D1 protein in a way, which resulted in reduced binding of phenylureas and triazines as well.

Another novel mutant was identified, when field accessions of Poa annua with resistance to PS II inhibitors, collected in Western Oregon, were analyzed after amplification of the herbicide-binding region (933 base pair fragment) of the chloroplast $p s b$ A gene using PCR.

Sequence analysis of the fragment from a mutant with resistance to diuron and metribuzin (resistance factors between 10 and 20) revealed a substitution from valine 219 to isoleucine in the $\mathrm{D} 1$ protein encoded by the $p s b \mathrm{~A}$ gene. This amino 
acid substitution was previously identified after mutagenesis of laboratory cultures of algae and cell cultures of Chenopodium rubrum. The finding of a valine-219 to isoleucine substitution in Poa annua, however, was the first reported case of a weed species with resistance to PS II inhibitors in the field, due to a psbA mutation other than at position 264. As previously mentioned, electron transfer processes in the PS II reaction center of weeds with a mutation at position 264 were slowed and the ecological fitness of the mutants was reduced. In contrast, no effect on electron transfer in the PS II reaction center was found for the Poa annua mutant with the valine 219 to isoleucine change, and it was supposed that this mutant may be ecologically as fit as the wild type [29].

Inhibitors of Acetyl-CoA Carboxylase (ACCase) Acetyl-CoA carboxylase catalyzes the carboxylation of acetyl-CoA, which results in the formation of malonyl-CoA. In the plastids this reaction is the initial step of de novo fatty acid biosynthesis and hence of crucial importance in plant metabolism. Species of the Poaceae family (grasses) have in their plastids a homomeric, multifunctional form of ACCase with the following domains: biotin carboxy carrier protein (BCCP), biotin carboxylase (BC) and carboxyltransferase (CT). Other monocotyledonous species, so far examined, and most dicotyledonous species have in their plastids a heteromeric, multisubunit type of ACCase with the BCCP, BC and CT domains encoded on separate subunits. In addition all di- and monocotyledons, including the Poaceae, have a cytosolic ACCase, which belongs to the homomeric type. The ACCase-inhibiting herbicides inhibit only the plastidic homomeric ACCase in grasses (Poaceae), but not the plastidic heteromeric form of other mono- and dicotyledonous species nor the homomeric ACCase in the cytosol. Therefore, these herbicides selectively have a lethal effect only on grass species, while they are tolerated by other monocotyledonous and by dicotyledonous species. There are two different chemical groups of ACCase inhibitors, the aryloxyphenoxypropionates (APPs) and the cyclohexanediones (CHDs), which have developed in the past 15 to 20 years to a very important herbicide family with selective action on a broad spectrum of grass weed species.

Target-site resistance of biotypes to ACCase inhibitors has up to now been confirmed for quite a few grass weed species of economic importance. The earliest cases of target-site based resistance were reported for biotypes of Lolium multiflorum from Oregon, USA [30] and of Lolium rigidum from Australia [31].

ACCase prepared from the resistant L. multiflorum biotype, which had been selected by field use of diclofop, was inhibited by the APPs diclofop, haloxyfop and quizalofop with $\mathrm{IC}_{50} \mathrm{~s}$ (herbicide conc. needed for $50 \%$ enzyme inhibition) that were 28-, 9- and 10-times higher than for ACCase from a susceptible biotype. There was no cross-resistance to the CHD herbicides sethoxydim or clethodim [32]. ACCase resistance was subsequently also confirmed for L. multiflorum biotypes from other countries. In a resistant biotype selected by diclofop in Normandy, the resistance factor (ratio of the $\mathrm{IC}_{50}$ for ACCase from the resistant to the $\mathrm{IC}_{50}$ for ACCase from the susceptible biotype) was 19 for diclofop and 5 for haloxyfop, but only 2 for the CHDs clethodim and sethoxydim [33]. Interestingly, 
a different ACCase resistance pattern was found for the resistant L. multiflorum biotype Yorks A2, though field selection was apparently also mainly by diclofop. Resistance factors were 3 and 9, respectively, for the APPs diclofop and fluazifop, but 20 for the CHD herbicide cycloxydim [34].

First biotypes of Lolium rigidum with target-site resistance to ACCase inhibitors were identified in the early 1990s in Australia. Selection either with an APP or a CHD herbicide resulted in target-site cross-resistance to both herbicide groups. But, regardless of whether selection was by an APP or a CHD compound, the level of resistance in these biotypes was higher to APP than to CHD herbicides. ACCase resistance factors were 30-85 for diclofop, >10-216 for haloxyfop and 1-8 for sethoxydim $[31,35,36]$.

Biotypes with target-site-based resistance to ACCase inhibitors were also selected in wild oat species (Avena fatua, A. sterilis). The resistance patterns were found to be variable. For example, the resistance factors for ACCase from the Canadian A. fatua biotype UM1 were 105 for sethoxydim, 10 for tralkoxydim, and 10 for diclofop and fenoxaprop, whereas for the Avena fatua biotype UM33 from Canada the ratios were 10.5 for fenoxaprop, 1.2 for diclofop, 5 for sethoxydim and 1.7 for tralkoxydim. It was proposed that this was due to different point mutations, each being associated with a characteristic resistance pattern [37]. Another reason could be the frequency of homozygote and heterozygote resistant and susceptible plants within a tested population.

During resistance studies with Alopecurus myosuroides populations from the UK two biotypes, Oxford A1 and Notts. A1, were identified, which were highly resistant to fenoxaprop, diclofop, fluazifop and sethoxydim due to an insensitive ACCase. Genetic studies revealed that the target-site resistance in the two A. myosuroides biotypes was monogenic and nuclear inherited, with the resistant allele showing complete dominance [38].

Target-site based resistance to ACCase has also been reported for several other grass weeds, e.g., two biotypes of Setaria viridis from Manitoba, Canada, one of them (UM8) conferring high levels of ACCase insensitivity to fenoxaprop and sethoxydim, while the ACCase of biotype UM 131 was highly insensitive to sethoxydim, but only moderately to fenoxaprop (reviewed in Ref. [36]). Biotypes of Setaria faberi and Digitaria sanguinalis, obtained in a vegetable cropping system in Wisconsin, USA, had an ACCase highly insensitive to sethoxydim and moderately insensitive to clethodim and fluazifop [39].

Based on the patterns of target-site-based cross-resistance of weeds to APP and CHD herbicides it was postulated that the two classes of ACCase inhibitors do not bind in identical manner to the target site ("overlapping binding sites"), and that different point mutations at the target enzyme account for variable resistance patterns. Molecular research with chloroplastic ACCase from wheat indicated first that a 400-amino acid region in the carboxyl transferase (CT) domain is involved in insensitivity to both APP and CHD herbicides [40]. Follow-up research with chloroplastic ACCase of Lolium rigidum showed that resistance to ACCase inhibitors was due to a point mutation which resulted in an isoleucine to leucine change in the CT domain of the enzyme [41]. Tal and Rubin have investigated the molec- 
ular basis of ACCase resistance in a Lolium rigidum biotype from Israel with resistance to CHD and APP herbicides [42]. After amplification by PCR of a 276-bp DNA encoding the CT domain of ACCase they found also in this resistant biotype a substitution of a single isoleucine by leucine. Inheritance studies of the same authors suggested that the alteration of ACCase in L. rigidum was governed by a single nuclear co-dominant gene.

It was shown that a point mutation resulting in an isoleucine to leucine substitution within the chloroplastic ACCase CT domain is also responsible for target-site resistance of Avena fatua [43] and of Alopecurus myosuroides [44]. Furthermore, in Setaria viridis biotype UM 131 a point mutation resulting in an isoleucine to leucine change of ACCase was detected [45]. The mutant leucine ACCase allele in this species was characterized to be dominant. No negative effect was detected on ACCase function of the mutant. It was suggested that the change in ACCase conformation caused by the isoleucine to leucine mutation is only minor, but sufficient to prevent or strongly reduce herbicide binding to the enzyme. Finally, also in Alopecurus myosuroides, an isoleucine to leucine substitution in the ACCase is associated with resistance to ACCase inhibitors [44]. These authors also pointed to the very interesting fact that the leucine found in the plastidic homomeric ACCase of mutated resistant grass weeds is also found in the heteromeric plastidic enzyme of non-grass species and in the cytosolic homomeric enzymes that are "naturally" resistant to these herbicides. Hence the selective action of ACCase-inhibiting herbicides appears to reside at this enzyme site.

Further studies by Délye and coworkers with Alopecurus myosuroides accessions from different sites in France shed more light on the molecular basis of the different resistance patterns to ACCase inhibitors. The isoleucine to leucine mutation (position 1781) resulted in resistance to fenoxaprop, diclofop and cycloxydim, but not to clodinafop and haloxyfop, while a newly discovered mutation of isoleucine to asparagine in position 2041 conferred resistance to fenoxaprop, diclofop, clodinafop and haloxyfop, but not to cycloxydim. Both resistance alleles can occur in the same plant and both are dominant, thus giving rise to plants that are resistant to the total spectrum of the above-mentioned herbicides [46]. Meanwhile, additional point mutations were identified in Alopecurus myosuroides that gave rise to insensitive ACCase due to exchange of one amino acid: Trp to Cys (pos. 2027), Asp to Gly (pos. 2078) and Gly to Ala (pos. 2096). The resistance patterns originating from these mutations gave further support to overlapping binding sites for APP and CHD herbicides at the ACCase enzyme [47].

Recently PCR amplification and sequencing of plastidic ACCase domains involved in herbicide resistance has been employed to screen a spectrum of 29 grass species for target-site-based resistance to ACCase inhibitors by direct comparison of the sequences of plastidic ACCase around the critical codons [48]. The authors found that, in Poa annua and Festuca rubra, a leucine residue occurred at position 1781, while the wild types of all other grass species had an isoleucine in this position. Poa annua and F. rubra are already known from enzyme inhibition tests to possess a plastidic ACCase that is markedly less susceptible to ACCase inhibitors than the ACCase of other grass species. Thus, the leucine in position 
1781 can clearly be regarded as the basis or a substantial part of the natural inherent tolerance of both species to ACCase-inhibiting herbicides.

A different mechanism of target-site resistance to ACCase inhibitors to be mentioned here was identified in a Sorghum halepense biotype from Virginia, USA, which was selected in the field by quizalofop applications. The resistance level of this biotype in vivo was relatively low, with resistance factors (based on $\mathrm{ED}_{50}$ values) ranging between 2.5 and 10 for quizalofop, sethoxydim and fluazifop. No difference was found between herbicide susceptibility of ACCase from the resistant biotype and a susceptible standard. However, the specific activity of ACCase in the resistant biotype was found to be $2-3 \times$ greater than in susceptible plants. The results suggested that an overproduction of ACCase was the mechanism that conferred a moderate level of resistance to these herbicides. Owing to the enzyme overproduction the resistant biotype was, presumably, able to sustain a level of malonyl-CoA production necessary for survival of herbicide treatment. This was so far the only reported case for this mechanism in a naturally occurring biotype [49].

Inhibitors of Acetolactate Synthase (ALS/AHAS) The enzyme acetolactate synthase (ALS) plays in plants an essential role in branched-chain amino acid biosynthesis. In the pathway leading to valine and leucine, ALS catalyzes the formation of 2-acetolactate from two pyruvate molecules, and in the pathway to isoleucine the formation of 2-acetohydroxybutyrate from 2-ketobutyrate and pyruvate. Due to this double function the enzyme is also called with a more general term acetohydroxyacid synthase. ALS is inhibited by several groups of herbicides, mainly the sulfonylureas (SUs), imidazolinones (IMIs), triazolopyrimidines (TPs), pyrimidinylthiobenzoates(PTBs) and sulfonylaminocarbonyltriazolinone (SCTs) (see Chapter 2.1, M. E. Thompson).

Resistant biotypes being reported in the early 1990s were selected by chlorsulfuron or metsulfuron-methyl in wheat-growing areas or by sulfometuron-methyl in non-crop areas. While resistance of Lolium rigidum to ALS-inhibitors was attributed to enhanced herbicide metabolism [50] it was shown, for Lolium perenne and dicotyledonous species like Stellaria media, Kochia scoparia, Salsola iberica and Lactuca serriola, that resistant biotypes had a mutated ALS with reduced susceptibility to ALS-inhibiting herbicides [51-53]. The $\mathrm{IC}_{50} \mathrm{~S}$ for sulfonylureas, which were determined in vitro with ALS isolated from Stellaria media, Salsola iberica and Lolium perenne, increased 4- to 50-fold in the resistant biotypes. Smaller increases, about 2- to 7-fold, were determined in the same biotypes for the imidazolinone herbicide imazapyr [53].

Later ALS-inhibitors were developed for selective use in rice and led to the selection of resistant rice weed biotypes. A biotype of Monochoria vaginalis, discovered in Korea, showed high levels of cross-resistance to bensulfuron-methyl, pyrazosulfuron-ethyl and flumetsulam. Resistance factors determined for ALS in vitro were 158 to bensulfuron-methyl and 58 to flumetsulam, but only 1.6 to imazaquin [54]. In rice fields in Japan a biotype of Scirpus juncoides was selected, which exhibited a high degree of resistance to imazasulfuron (resistance factor 
of 271, calculated from $\mathrm{ED}_{50} \mathrm{~s}$ for growth inhibition). Inhibition tests with isolated ALS revealed an $\mathrm{IC}_{50}$ of $15 \mathrm{~nm}$ for the enzyme from susceptible plants, but of more than $3000 \mathrm{~nm}$ for ALS isolated from the resistant biotype, suggesting that resistance was due to an altered ALS enzyme [55].

It appears that reduced sensitivity of the target enzyme is the predominant cause of resistance to ALS inhibitors, and that resistance is conferred by a single, dominant or at least partial dominant, nuclear-encoded gene. Molecular studies revealed that resistance is caused by single substitution of one of five highly conserved amino acids in the ALS enzyme. These are the following (amino acid number standardized to the Arabidopsis thaliana sequence): Pro197, Ala122 and Ala205, located at the amino-terminal end, Trp574 and Ser653, located near the carboxy-terminal end [56]. For more details see also Chapter 2.1 (M. E. Thompson).

In the ALS of a Lactuca serriola biotype, highly resistant to SUs and moderately resistant to IMIs, Pro197 was substituted by His. The pyruvate binding domain on the ALS enzyme was not found to be altered by the mutation [57]. From Kochia scoparia it was reported that several substitutions of Pro197 by another amino acid (Thr, Arg, Leu, Gln, Ser, Ala) will confer resistance to sulfonylureas [58]. In the same species, it was found later that a substitution of Trp574 by Leu will also cause resistance to sulfonylureas and in addition cross-resistance to imidazolinones [59]. The latter substitution was also detected in resistant biotypes of several other dicotyledonous weed species.

In a biotype of Amaranthus retroflexus from Israel, resistance was caused by a change of Pro197 to Leu. This biotype exhibited cross-resistance to sulfonylureas, imidazolinones, triazolopyrimidines and to pyrithiobac-sodium in vivo and on the ALS enzyme level [60]. In mutations of Amaranthus rudis, Ser653 was found to be exchanged by Thr or Asn. These were only resistant to imidazolinones [61].

From the multiplicity of amino acid substitutions it was concluded that the herbicide-binding site of the ALS can tolerate substitutions of each of the five conserved amino acids without major consequences to normal catalytic functions. It was, therefore, speculated that the herbicide-binding site and the active site of ALS are different, though they are probably in close proximity. In absence of herbicide selection, the weed biotypes with mutated ALS showed, in most cases, no reduction or only negligible reduction of fitness (reviewed in Ref. [56]).

Glyphosate Resistance to glyphosate has now appeared in several weed species. In resistant accessions of Eleusine indica from Malaysia it was found to be due to point mutations of the target enzyme EPSP synthase. By PCR amplification and sequence analysis of an EPSP synthase fragment an exchange of Pro106 by Ser was found in two resistant accessions, and an exchange of Pro106 by Thr in a third resistant accession [62].

\subsubsection{Nontarget-site Resistance by Enhanced Metabolic Detoxification}

Crop and weed species dispose of enzyme systems that catalyze the metabolic conversion of herbicides. The metabolites, which are usually more polar than the 
parent compound, are either non-phytotoxic at all or have a reduced phytotoxic potential. Among the various enzyme systems involved in metabolic herbicide detoxification, two are of particular importance in weeds and crops. One is the cytochrome-P450 monooxygenase system, which catalyzes oxidative transformations of the herbicide molecule (e.g., hydroxylations and oxidative dealkylations). Actually, it is a large enzyme family consisting of multiple cytochrome-P450 monooxygenases with diverse substrate specificities. The other enzyme is the glutathione-S-transferase (GST) family, catalyzing conjugation reactions that result in a nucleophilic displacement of aryloxy moieties, chlorine or other substituents by the tripeptide glutathione. Also the GSTs occur in various isoforms which differ in their catalytic properties.

The herbicide tolerance of crop species has been found to be based frequently on differential rates of metabolic herbicide detoxification in crop and weed species: while rates of herbicide detoxification in the weed species are too low to prevent binding of a lethal herbicide dosage at the target site, the tolerant crop is able to metabolically detoxify the herbicide with such a high rate that binding of the herbicide at the target site in sufficient amounts to cause irreversible herbicidal effects will be prevented. If weed biotypes with an improved ability for herbicide detoxification, comparable to the tolerant crop species, occur in a population they will survive herbicide application and will thus be selected.

To date quite a few weed biotypes have been described for which herbicide resistance was related to enhanced metabolic herbicide detoxification. Several cases have been published for Lolium rigidum. An early paper of Christopher et al. reported that excised shoots of biotype SLR 31 from Australia, which was resistant to diclofop, exhibited cross-resistance to the sulfonylureas chlorsulfuron, metsulfuron-methyl and triasulfuron [63]. The metabolite pattern of chlorsulfuron was identical in the resistant biotype and a susceptible standard, but the resistant biotype metabolized the herbicide more rapidly. The pathway of chlorsulfuron detoxification in Lolium rigidum was similar to the one described for wheat, ring hydroxylation being followed by glucose conjugation. The time course of chlorsulfuron metabolism in the Lolium rigidum biotype SR 4/84 (resistant to diclofop and cross-resistant to chlorsulfuron) was analyzed separately in shoots and roots. The half-life of chlorsulfuron in susceptible plants was longer in the roots $(13 \mathrm{~h})$ than in the shoots $(4 \mathrm{~h})$ and was reduced in the resistant biotype to 3 and $1 \mathrm{~h}$, respectively. Detoxification of the herbicide by ring hydroxylation, likely catalyzed by a cytochrome-P450 monooxygenase with subsequent glucose conjugation was enhanced in the resistant biotype [50].

Two other Lolium rigidum biotypes from Australia (WLR2 and VLR69) developed metabolism-based resistance to PSII inhibitors. WLR2 came from a field with selection pressure by atrazine and amitrole, but never by phenylureas, and VLR69 from a field with selection pressure by diuron and atrazine. Both biotypes were resistant to triazines, and, despite the field selection by atrazine, resistance was more pronounced to the structurally related simazine. Furthermore, both biotypes were resistant to chlorotoluron, though only VLR69 was previously exposed to phenylureas. Analytical work revealed that in both resistant biotypes 
metabolism of chlorotoluron and simazine was enhanced, and that the main route of metabolism was via $\mathrm{N}$-dealkylation reactions. This type of reaction and the fact that herbicide metabolism was inhibited by 1-aminobenzotriazole (ABT), an inhibitor of cytochrome-P450 monooxygenases, suggested increased activity of cytochrome-P450 monooxygenases in the resistant biotypes [64, 65]. The mechanism of phenylurea resistance of Lolium rigidum biotypes from Spain has been studied [66]: A biotype (R3) selected in the field by applications of diclofop plus isoproturon or plus chlorotoluron had in vivo resistance factors $\left(E_{50} R / E D_{50} S\right)$ of about 9.3 and 5.5 to chlorotoluron and isoproturon, respectively, and was also resistant to a broad spectrum of other phenylureas. Metabolism studies with chlorotoluron, in absence and presence of the cyochrome-P450 monooxygenase inhibitor 1-aminobenzotriazole, suggested that resistance was due to enhanced ability to degrade the molecule to non-toxic ring-alkylhydroxylated intermediates suitable for follow-up conjugation reactions. Several biotypes of Lolium multiflorum from the UK with resistance to diclofop have been analyzed [34]. While one biotype had an insensitive ACCase, resistance of three other biotypes could be attributed to enhanced metabolism of this herbicide.

The resistance of the grass weed Phalaris minor to isoproturon and of the dicotyledonous weed species Abutilon theophrasti to atrazine has also been attributed to enhanced metabolism. GST was the enzyme responsible for atrazine detoxification in A. theophrasti [67], whereas in P. minor the cytochrome P450 monooxygenase was probably involved in the enhanced detoxification of isoproturon [68].

The increasing occurrence of Alopecurus myosuroides resistance to herbicides in several European countries prompted research on resistance mechanisms also in this species. Aside from target-site-based resistance, cases of resistance due to enhanced herbicide metabolism had also been reported. Two biotypes, Peldon A1 and Lincs. E1, with in vivo resistance factors to isoproturon of 28 and 2.6, respectively, metabolized this herbicide faster than a susceptible standard. The rate of metabolism was higher in Peldon than in Lincs. Addition of the cytochromeP 450 monooxygenase inhibitor 1-aminobenzotriazole decreased the rate of chlorotoluron metabolism and correspondingly increased phytotoxicity, suggesting the involvement of the cytochrome-P450 monooxygenase system in the detoxification of the herbicide. The major detoxification reaction in these biotypes appeared to be the formation of a hydroxymethylphenyl metabolite [69].

The same biotypes, Peldon A1 and Lincs. E1, are also resistant to the graminicide fenoxaprop, which is used for selective control of A. myosuroides and other grass weeds in cereals, mainly wheat. On a whole plant level, Lincs. E1 was more resistant than Peldon A1. The selectivity of this herbicide has been attributed to rapid detoxification by GST-catalyzed conjugation in the cereal species. In both resistant $A$. myosuroides biotypes GST activities towards fenoxaprop were found to be increased to a similar degree, when compared with a susceptible biotype. This was due to increased expression of a constitutive GST and to expression of two novel GST isoenzymes. Furthermore, glutathione levels were increased in the resistant biotypes, in Peldon more than in Lincs. The data pointed to an involve- 
ment of GST activity and glutathione levels in the resistance to fenoxaprop, though the lack of correlation to whole plant resistance of these biotypes did not permit definite conclusions [70]. A range of European A. myosuroides biotypes with resistance to fenoxaprop has been investigated [71]. Several of these biotypes, in particular one from Belgium, detoxified this herbicide with increased rates. The biotype from Belgium had also the highest GST activity towards the unspecific substrate CDNB, but GST activity towards the herbicide was not tested.

Studies on the mode of inheritance of metabolic herbicide resistance in Alopecurus myosuroides did not result in a uniform picture. It was reported that a single gene was responsible for metabolism-based resistance in a biotype resistant to fenoxaprop and flupyrsulfuron [72], while in another biotype resistance to chlorotoluron was attributed to more than one gene [73].

Different to the cases described above, the herbicide propanil is detoxified in rice and weed species by the action of an aryl acylamidase (aryl-acylamine amidohydrolase). High activity of this enzyme in rice confers crop tolerance. In Colombia, a biotype of Echinochloa colona was found that is resistant to propanil. Enzyme tests with extracts from this biotype revealed an about three-fold higher activity of aryl acylamidase in the resistant than in a susceptible biotype. It was concluded that resistance of the E. colona biotype is based on enhanced propanil detoxification [74].

\subsubsection{Nontarget-site Resistance by Altered Herbicide Distribution}

Cases of nontarget-site resistance by altered herbicide distribution have been reported for two important herbicides, paraquat and glyphosate.

Intensive use of the herbicide paraquat has resulted in the evolution of resistance in various weed species. Intensive research on the resistance mechanisms was mainly carried out with resistant biotypes from Hordeum spp. and Conyza spp., and altered distribution of the herbicide in the resistant weeds was suggested as the cause - or at least the partial cause - of resistance. In resistant Con$y z a$ canadensis it was supposed that a paraquat inducible protein may function by carrying paraquat to a metabolically inactive compartment, either the cell wall or the vacuole. This sequestration process would prevent the herbicide from getting in sufficient amounts into the chloroplasts as the cellular site of paraquat action. Inhibitors of membrane transport systems, e.g., $N, N$-dicyclohexylcarbodiimide (DCCD), caused a delay in the recovery of photosynthetic functions of the paraquat-resistant biotype, when given after the herbicide. These transport inhibitor experiments supported the involvement of a membrane transporter in paraquat resistance [75].

Translocation studies with two paraquat-resistant biotypes of Hordeum leporinum revealed that the basipetal transport of paraquat in resistant $H$. leporinum was much reduced compared with susceptible plants. It was concluded that the resistance to paraquat was the result of the reduced herbicide translocation out of the treated leaves [76]. One can suppose that also in this species herbicide sequestration may have been the primary cause for the altered long-distance transport. 
Independent populations of Lolium rigidum with resistance to glyphosate have been reported from different locations in Australia. One of them, with a ca. 10fold in vivo resistance to glyphosate, was used for intensive investigation of the mechanism of resistance. Neither a modification of the target enzyme EPSP synthase nor of herbicide metabolism contributed to the resistance in this case. Translocation studies after foliar application revealed, however, that in the resistant biotype glyphosate accumulated preferentially in the leaf tips, while in susceptible plants accumulation was stronger in the leaf bases and the roots. This result suggested a shift of glyphosate transport in the resistant plants from the phloem to the xylem system. It was speculated that the resistant biotype might have lost in efficiency to load glyphosate into the symplast. Thus more of the herbicide would remain in the apoplast and be translocated acropetally with the transpiration stream, while the concentration of glyphosate in the plastids of the sensitive meristematic tissues at the shoot base and in the roots would be reduced [77].

\subsubsection{Multiple Resistance}

As defined above, multiple resistance means that more than one resistance mechanism occurs in a weed population or an individual plant. This can either mean that a target site-based and a nontarget-site based mechanism occur in the same biotype, or that a biotype is resistant to herbicides with different mechanisms of action. Multiple resistance can result in resistance of a weed biotype to a very broad range of herbicide chemistries. Multiple resistance has been reported for several weed species, particularly for Lolium rigidum, Alopecurus myosuroides, Kochia scoparia, Conyza canadensis and Amaranthus rudis. It developed to a serious extent particularly in Australian biotypes of Lolium rigidum, probably as a result of agricultural conditions paired with biological characteristics of this weed (cross pollinating species with high genetic variability and seed production and high plant numbers per area).

Multiple resistance can develop by selection with a single herbicide or by selection with several herbicides, which are either used sequentially or simultaneously. Furthermore, cross-pollinating species can become multiple resistant, when two individuals, each with a different resistance mechanism, cross. An example for the selection of multiple resistance by a single herbicide (the ALS inhibitor chlorsulfuron) is the Lolium rigidum biotype WLR1. This biotype had as main mechanism of resistance an ALS with reduced sensitivity to chlorsulfuron, sulfometuron and imazamethabenz, and as additional mechanism enhanced metabolism of chlorsulfuron [78]. Extreme cases of multiple resistance, due to an application history of many herbicides, were reported from Australia for several Lolium rigidum biotypes. As an example, biotype VLR69 possessed the following mechanisms: enhanced metabolism of ACCase-inhibiting herbicides, resistant form of the ACCase enzyme, enhanced metabolism of the ALS-inhibitor chlorsulfuron, and in addition a resistant form of the ALS enzyme in 5\% of the population [36].

Selection of multiple resistance after sequential use of different herbicides has been described for a biotype of Kochia scoparia from North America. Many years 
of triazine usage resulted in the selection of a biotype with target-site resistance of the D1 protein in photosystem II. By subsequent usage of ALS inhibitors, a point mutation in the gene encoding for ALS was selected in addition, which made this biotype also target-site-resistant to sulfonylureas and imidazolinones [59].

Obviously, multiple resistance leads to complex patterns of broad herbicide resistance, particularly in cross-pollinating weed species. This seriously restricts the remaining options of chemical weed control in agricultural practice.

\section{References}

1 I. Heap, personal communication. http://www.weedscience.com, 2006.

2 I. Heap, H. LeBaron, In: Herbicide Resistance and World Grains. eds. S. B. Powles, D. L. Shaner CRC Press, Boca Raton, FL, 2001, 1-22.

3 HRAC, Classification of Herbicides According to Mode of Action, http:// www.plantprotection.org/HRAC/, 2005.

4 C. A. Mallory-Smith, E. J. Retzinger, Weed Technol., 2003, 17, 605-619.

5 CropLife Australia, in: Managing resistance, Herbicide Mode of Action Groups, http://www.croplifeaustralia. org.au, update 2005, 1-3.

6 BCS, Internal communication, 2004.

7 C. James, The International Service for the Acquisition of Agri-biotech Applications, http://www.ISAAA.org, 2005.

8 H. J. Beckie, Can. J. Plant Sci., 2006, in press.

9 National Agricultural Statistics Service, Agricultural Chemical Usage - 1996/2000/2004 Field Crops Summary (U.S. Dept. Agric. Washington DC).

10 S. O. Duke, Proc. Workshop of Ecological Effects of Pest Resistance Genes in Managed Ecosystems, Bethesda, MD, 1999.

11 M. D. K. Owen, Proc. Bright. Crop Prot. Conf., 1997, 3, 955-963.

12 M. D. K. Owen, Integr. Crop Manag. Conf., Iowa State Univ., 2005, 55-59.

13 J. A. Bird, A. J. Eagle, W. R. Horwath, M. W. Hair, E. E. Zilbert, C. v. Kessel, Calif. Agric., 2002, 02, 69-75.

14 M. Walsh, Austr. Farm J., 2003, 03, 40-41.
15 F. H. D‘Emden, R. S. Llewellyn, M. P. Burton, Tech. Forec. Soc., 2003. 03, 40-41.

16 P. Neve, A. J. Diggle, F. P. Smith, S. B. Powles, Weed Res., 2003, 43, 418-427.

17 T. Hyvönen, J. Salonen, Plant Ecol., 2002, 154, 73-91.

18 B. E. Valverde, in: Weed Management for Developing Countries, ed. R. Labrada, FAO, Rome, 2003.

19 J. Gasquez, personal communication, 2003.

20 B. Chauvel, J. P. Guillemin, N. Colbach, J. Gasquez, Crop Prot., 2001, 20, 127-137.

21 S. B. Powles, D. L. Shaner (eds.), Herbicide Resistance and World Grains. CRC Press, Boca Raton, FL, 2001.

22 P. Böger, Biol. Z., 1983, 13.Jahrg., Nr.6, 170-177.

23 D. R. Ort, W. H. Ahrens, B. Martin, E. W. Stoller, Plant Physiol., 1983, 72, 925-930.

24 C. Sundby, W. S. Chow, J. M. Anderson, Plant Physiol., 1993, 103, 105-113.

25 G. Zurawski, H. Bohnet, P. Whitfeld, W. Bottomley, Proc. Natl. Acad. Sci. U.S.A., 1982, 79, 7699-7703.

26 A. Trebst, in: Herbicide Resistance in Weeds and Crops, eds. J. C. Caseley, G. W. Cussans, R. K. Atkin, Butterworth-Heinemann, Oxford, 1991, 145-164.

27 A. Trebst, in: Molecular genetics and evolution of pesticide resistance, ed. T. M. Brown, ACS Symposium series, ACS, Washington DC, 1996, 645, 44-51.

28 J. G. Masabni, B. H. Zandstra, Weed Sci., 1999, 47, 393-400. 
29 L. W. Mengistu, G. W. MuellerWarrant, A. Liston, R. E. Barker, Pest Manag. Sci., 2000, 56, 209-217.

30 C. E. Stanger, A. P. Appleby, Weed Sci., 1989, 37, 350-352.

31 J. A. M. Holtum, S. B. Powles, Bright. Crop Prot. Conf. - Weeds, 1991, 1071-1078.

32 J. W. Gronwald, C. V. Eberlein, K. J. Betts, R. J. Baerg, N. J. Ehlke, D. L. Wyse, Pestic. Biochem. Physiol., 1992, 44, 126-139.

33 R. De Prado, J. González-Gutiérrez, J. Menéndez, J. Gasquez, J. W. Gronwald, R. Giménez-Espinosa, Weed Sci., 2000, 48, 311-318.

34 K. M. Cocker, D. S. Northcroft, J. O. D. Coleman, S. R. Moss, Pest Manag. Sci., 2001, 57, 587-597.

35 F. J. Tardif, J. A. M. Holtum, S. B. Powles, Planta, 1993, 190, 176-181.

36 S. B. Powles, C. Preston, The Herbicide Resistance Action Committee Monograph Number 2, 1995.

37 M. D. Devine, Pestic. Sci., 1997, 51, 259-264.

38 S. R. Moss, K. M. Cocker, A. C. Brown, L. Hall, L. M. Field, Pest Manag. Sci., 2003, 59, 190-201.

39 D. Volenberg, D. Stoltenberg, Weed Res., 2002, 42, 342-350.

40 T. Nikolskaya, O. Zagnitko, G. Tevzadze, R. Haselkorn, P. Gornicki, Proc. Natl. Acad. Sci. U.S.A., 1999, 96, 14647-14651.

41 O. Zagnitko, J. Jelenska, G. Tevzadze, R. Haselkorn, P. Gornicki, Proc. Natl. Acad. Sci. USA, 2001, 98, 6617-6622.

42 A. Tal, B. Rubin, Pest Manag. Sci., 2004, 60, 1013-1018.

43 M. J. Christoffers, M. L. Berg, C. G. Messersmith, Genome, 2002, 45, 1049-1056.

44 A. C. Brown, S. R. Moss, Z. A Wilson, L. M. Field, Pestic. Biochem. Physiol., 2002, 72, 160-168.

45 C. Délye, T. Wang, H. Darmency, Planta, 2002, 214, 421-427.

46 C. Délye, C. Straub, A. Matéjicek, S. Michel, Pest Manag. Sci., 2003, 60, 35-41.

47 C. Délye, X.-Q. Zhang, S. Michel, A. Matéjicek, S. B. Powles, Plant Physiol., 2005, 137, 794-806.
48 C. Délye, S. Michel, Weed Res., 2005, 45, 323-330.

49 K. W. Bradley, J. Wu, K. K. Hatzios, E. S. Hagood Jr., Weed Sci., 2001, 49, 477-484.

50 J. C. Cotterman, L. L. Saari, Pestic. Biochem. Physiol., 1992, 43, 182-192.

51 C. A. Mallory-Smith, D. C. Thill, M. J. Dial, Weed Technol., 1990, 4, 163.

52 L. L. Saari, J. C. Cotterman, M. M. Primiani, Plant Physiol., 1990, 93, 55.

53 L. L. Saari, J. C. Cotterman, W. F. Smith, M. M. Primiani, Pestic. Biochem. Physiol., 1992, 42, 110-118.

54 I. T. Hwang, K. H. Lee, S. H. Park, B. H. Lee, K. S. Hong, S. S. Han, Pestic. Biochem. Physiol., 2001, 71, 69-76.

55 Y. Tanaka, Pestic. Biochem. Physiol., 2003, 77, 147-153.

56 P. J. Tranel, T. R. Wright, Weed Sci., 2002, 50, 700-712.

57 M. J. Guttieri, C. V. Eberlein, C. A. Mallory-Smith, D. C. Thill, D. L. Hoffmann, Weed Sci., 1992, 40, 670-676.

58 M. J. Guttieri, C. V. Eberlein, D. C. Thill, Weed Sci., 1995, 43, 175-178.

59 M. J. Foes, L. Liu, G. Vigue, E. W. Stoller, L. M. Wax, P. J. Tranel, Weed Sci., 1999, 47, 20.

60 M. Sibony, A. Michel, H. U. Haas, B. Rubin, K. Hurle, Weed Res., 2001, 41, 509-522.

61 W. L. Patzold, P. J. Tranel, Proc. N. Cent., Weed Sci. Soc., 2001, 56, 67.

62 C. H. Ng, R. Wickneswari, S. Salmijah, Y. T. Teng, B. S. Ismail, Weed Res., 2003, 43, 108-115.

63 J. T. Christopher, S. B. Powles, D. R. Liljegreen, J. A. M. Holtum, Plant Physiol., 1991, 95, 1036-1043.

64 M. W. M. Burnet, B. R. Loveys, J. A. M. Holtum, S. B. Powles, Pestic. Biochem. Physiol., 1993, 46, 207-218.

65 M. W. M. Burnet, B. R. Loveys, J. A. M. Holtum, S. B. Powles, Planta, 1993, 190, 182-189.

66 R. De Prado, J. L. De Prado, J. Menendez, Pestic. Biochem. Physiol., 1997, 57, 126-136.

67 M. P. Anderson, J. W. Gronwald, Plant Physiol. 1991, 96, 104-109. 
68 S. Singh, R. C. Kirkwood, G. Marshall, Pestic. Biochem. Physiol., 1998, 59, 143-153.

69 L. M. Hall, S. R. Moss, S. B. Powles, Pestic. Biochem. Physiol., 1995, 53, 180-192.

70 I. Cummins, S. Moss, D. J. Cole, R. Edwards, Pestic. Sci., 1997, 51, 244-250.

71 K. M. Cocker, S. R. Moss, J. O. D. Coleman, Pestic. Biochem. Physiol., 1999, 65, 169-180.

72 A. Letouzé, J. Gasquez, Theor. Appl. Genet., 2001, 103, 288-296.

73 B. Chauvel, Ph.D. Thesis, 1991, University of Paris-Orsay.
74 J. M. Leah, J. C. Caseley, C. R. Riches, B. Valverde, Pestic. Sci., 1994, 42, 281-289.

75 K. Halász, V. Sóos, B. Jóri, I. Rácz, D. Lásztity, Z. Szigeti, Acta Biol. Szegediensis, 2002, 46, 23-24.

76 C. Preston, C. J. Soar, I. Hidayat, K. M. Greenfield, S. B. Powles, Weed Res., 2005, 45, 289.

77 D. F. Lorraine-Colwill, S. B. Powles, T. R. Hawkes, P. H. Hollinshead, S. A. J. Warner, C. Preston, Pestic. Biochem. Physiol., 2003, 74, 62-72.

78 J. T. Christopher, S. B. Powles, J. A. M. Holtum, Plant Physiol., 1992, 100, 1909-1913. 